\title{
A new Scleromystax species (Siluriformes: Callichthyidae) from coastal rivers of Southern Brazil
}

\author{
Marcelo R. Britto* and Roberto E. Reis**
}

\begin{abstract}
The recently resurrected callichthyid catfish genus Scleromystax includes species occurring in several Brazilian coastal river basins from southern Bahia to southern Santa Catarina. Several character states, especially those related to sexual dimorphism, demonstrate the monophyly of Scleromystax. Examination of Scleromystax specimens sampled from streams in the Ilha de Santa Catarina and Nova Veneza, and the rio Mampituba basin, Santa Catarina and Rio Grande do Sul States, revealed that they constitute a new taxon, and thus the southernmost record for the genus. Scleromystax salmacis, new species, has coloration similar to that of $S$. macropterus, differing from that species mainly by the absence of a black spot on the base of the median caudal-fin rays, and transverse blotches along the body more irregular than those in S. macropterus. In addition to differences in coloration and external and osteological characters, the new species differs from S. barbatus and S. prionotos by its more rounded snout. The new taxon is also distinguished from its congeners by the presence of a single perforated dorsolateral body plate, similar to the condition found in some Aspidoras species, orientation of the ventral keel of the scapulocoracoid, and by the absence of sexually dimorphic features.
\end{abstract}

O gênero Scleromystax foi recentemente revalidado e inclui espécies distribuídas nas diversas bacias hidrográficas costeiras entre o sul do Estado da Bahia e o sul do Estado de Santa Catarina. O monofiletismo de Scleromystax é demonstrado por vários estados de caráter, sendo aqueles relacionados ao dimorfismo sexual os mais evidentes. O exame de exemplares de Scleromystax coletados em rios da Ilha de Santa Catarina e do município de Nova Veneza, e da bacia do rio Mampituba, Estados de Santa Catarina e Rio Grande do Sul, revelou que os mesmos representam uma nova espécie, sendo este o registro mais austral do gênero. Scleromystax salmacis, espécie nova, apresenta o colorido semelhante a S. macropterus, porém difere desta principalmente pela ausência de uma mancha arredondada e escura na base dos raios medianos da nadadeira caudal, e pelas manchas transversais ao longo do corpo serem mais irregulares que em $S$. macropterus. Além do colorido e de caracteres de morfologia externa e osteológicos, a nova espécie distingue-se de $S$. barbatus e $S$. prionotos pela forma mais arredondada do focinho. O novo táxon distingue-se de todos os seus congêneres pela presença de somente uma placa dorsolateral com poro da linha lateral, semelhante ao estado observado em algumas espécies de Aspidoras, orientação da quilha ventral do escápulocoracóide, e pela ausência de caracteres relacionados ao dimorfismo sexual.

Key words: Taxonomy, Systematics, Corydoradinae, Catfish.

\section{Introduction}

The recently resurrected genus Scleromystax Günther comprises a small monophyletic assemblage of catfishes previously assigned to Corydoras, which, however, are now considered to be more closely related to Aspidoras (Britto, 2003). Scleromystax is composed of three highly sexually dimorphic species endemic to small tributaries from several coastal river basins draining Brazilian southern and southeastern regions: S. barbatus (Quoy \& Gaimard), S. macropterus (Regan), and S. prionotos (Nijssen \& Isbrücker) (Reis, 2003). Each species has a relatively broad area of distribution that partially overlap: from around Trancoso, Bahia State, to the rio Ribeira de Iguape basin (Scleromystax prionotos); from the rio Paraíba do Sul basin to the rio Itapocu basin (S. barbatus); and from the rio Ribeira de Iguape basin to rivers draining into the baía de São Francisco (S. macropterus). Although the monophyly of Scleromystax was recently demonstrated (Britto, 2003), phylogenetic relationships of its species remains obscure. In addition, the taxonomic status of its species are only partially resolved.

During an ichthyological survey of the rio Mampituba system at the boundary between the Brazilian states of Santa

\footnotetext{
* Museu Nacional, Universidade Federal do Rio de Janeiro, Departamento de Vertebrados, Quinta da Boa Vista, 20940-040 Rio de Janeiro, RJ, Brazil. e-mail: mrbritto2002@yahoo.com.br

** Pontifícia Universidade Católica do Rio Grande do Sul, Laboratório de Ictiologia, Cx. Postal 1429, 90619-900 Porto Alegre, RS, Brazil. e-mail: reis@pucrs.br
} 
Catarina and Rio Grande do Sul, one of the authors (RER), together with other MCP ichthyologists, collected some specimens of a corydoradine catfish that were similar to Scleromystax macropterus. Additional material of this species was also found in samples from the Ilha de Santa Catarina, rio Ratones basin, and from Nova Veneza, rio do Cedro basin, Santa Catarina State. Examination of the preserved material revealed that this catfish was a new Scleromystax species, which differs from its congeners mainly by having their sexually dimorphic features very subtle and non-remarkable. This new species of Scleromystax is described herein and comments on the diagnosis of Scleromystax are provided.

\section{Material and Methods}

Morphometric and meristic data were taken following Reis (1997). Length of the ossified portion of the pectoral spine was measured from the spine-pectoral girdle articulation to distal tip of spine. Measurements were obtained with calipers to $0.1 \mathrm{~mm}$. Teeth and vertebral counts were taken only from cleared-and-stained (cs) specimens, prepared according to Taylor \& Van Dyke (1985). Vertebral counts include only free centra, with the compound caudal centra (preural $1+$ ural 1) counted as a single element. Lateral plate counts include all dorsolateral and ventrolateral plates, except for the small, irregular plates on the caudal peduncle. In the description, values for the holotype are marked with an asterisk. Nomenclature of latero-sensory canals follows Schaefer \& Aquino (2000), and that of preopercular pores follows Schaefer (1988). Osteological terminology follows Reis (1998), except for the use of parieto-supraoccipital instead of supraoccipital (Arratia \& Gayet, 1995), compound pterotic instead of pteroticsupracleithrum (Aquino \& Schaefer, 2002), and scapulocoracoid instead of coracoid (Lundberg, 1970), as adopted in Britto \& Lima (2003). Homologies of barbels follows Britto \& Lima (2003). Institutional abbreviations are according to Reis et al. (2003).

Comparative material: A list of the comparative material is available in Britto (2003). In addition, the following material was studied: Aspidoras sp. MNRJ 21269 (51); MNRJ 21270 (26, 2 cs); MNRJ 21708 (7); MNRJ 21709 (50, 2 cs); MNRJ 21710 (18, 1 cs); MNRJ 21711 (47); MNRJ 21712 (1); MNRJ 28407 (1); MZUSP 67194 (20); MZUSP 67195 (20); Corydoras lacerdai MNRJ 26017 (17, 4 cs); Scleromystax barbatus MNRJ 3795 (9); MNRJ 5781 (6); MNRJ 13439 (6); MNRJ 13445 (1); MNRJ 24297 (19); MZUSP 25044 (2); MZUSP 27026 (3); MZUSP 35506 (1); MZUSP 35507 (1); MZUSP 35520 (1); MZUSP 37723 (19); MZUSP 41796 (8); MCP 10604 (21); MCP 10609 (1); MCP 12182 (3); MCP 12248 (9); MCP 13812 (2); MCP 13845 (10); МCP 13865 (10); MCP 14254 (15); MCP 14255 (7); MCP 16458 (3); MCP 17811 (2); MCP 19215 (4); MCP 19801 (1); MCP 19806 (2); MCP 26954 (4); MCP 31604 (1); MCP 31605 (15); МCP 31609 (2); MCP 31611 (1); MCP 31612 (2); MCP 31613 (1); MCP 31619 (2); MCP 32199 (1); UFRJ 4437 (1 cs); UFRJ 4439 (1 cs); UFRJ 4440 (1 cs); UFRJ 4441 (1 cs); UFRJ 4443 (1 cs); UFRJ 4457 (2 cs); UFRJ 4526 (4 cs); Scleromystax macropterus MZUSP 24720 (12); MZUSP 25054 (2); MZUSP 36980 (1); MZUSP 42498
(4); MZUSP 42827 (2); MZUSP 83013 (17); MCP 17800 (2); MCP 17808 (2); MCP 17810 (1); MCP 26027 (3); MZUSP 83019 (5); UFRJ 202 (4); UFRJ 4442 (2 cs); Scleromystax prionotos MNRJ 10537 (holotype); MNRJ 13901 (6); MNRJ 17994 (5); MNRJ 22363 (1); MNRJ 22364 (2); MZUSP 61757 (2); MZUSP 62869 (5); MZUSP 69377 (3); MZUSP 69691 (1); MZUSP 80025 (3); MCP 34378 (1); MCP 34458 (1); UFRJ 4428 (2 cs); UFRJ 4430 (1 cs); UFRJ 4431 (1 cs); UFRJ 4432 (01 cs); UFRJ 4474 (1).

\section{Scleromystax salmacis, new species}

Figs. 1-2

Holotype. MCP 38388 (female, 36.7 mm SL) Brazil, Santa Catarina, Praia Grande, arroio Molha Coco in Vila Rosa nearly $5.5 \mathrm{~km}$ northwest from Praia Grande, 29¹0'14"S 4958' 53"W; V. A. Bertaco \& J. F. Pezzi da Silva, 25 Mar 2002.

Paratypes (all from Brazil, Santa Catarina). MCP 29299 (4, 1 cs, 33.2-37.2 mm SL) same data as holotype. MCP 23624 (1, 30.7 $\mathrm{mm}$ SL) Praia Grande, arroio Molha Coco in Vila Rosa nearly 5 km northwest from Praia Grande, 29¹0'13"S 4958'49"W; E. H. L. Pereira, R. E. Reis \& J. F. Pezzi da Silva, 21 Jul 1999. MCP 17801 (2, 41.3-48.2 mm SL) Nova Veneza, rio Cedro Alto, approx. 2838'S 49³0'W; S. Althoff, 12 Mar 1993. UFRJ 140 (2, 32.933.7 mm SL) Nova Veneza, creek ("canal") tributary of rio São Bento; F. A. Bockmann, 5 Mar 1990.

Non-type material (Brazil, Santa Catarina). MCP 28729 (24, 3 cs, 21.1-53.1 mm SL) Florianópolis, creek tributary of rio Ratones, 27³0’40"S 48²9'11"W; 25 Oct 2001. MCP 28744 (3, 33.8-41.9 mm SL) Florianópolis, creek tributary of rio Ratones, at Bairro Ratones, 27³0’31"S 48²9’33"W; 25 Oct 2001.

Diagnosis. Scleromystax salmacis differs from its congeners by the following features: presence of only one perforated dorsolateral body plate ( $v s$. none or 2-5 perforated dorsolateral body plates); ventral keel of scapulocoracoid orientated towards anterior margin of bone, its anterior portion surpassing horizontal through middle of mesial border of scapulocoracoid ( $v s$. keel parallel to posterior margin of the scapulocoracoid, not surpassing horizontal through middle of mesial border of bone); preopercular-opercular region similar in males and females, with only minute, scattered odontodes ( $v s$. males with developed odontodes inserted in fleshy papillae); and dorsal and pectoral fins equal in length on both sexes ( $v s$. dorsal and pectoral fins of males 2-3 times as long as those fins in females).

Among Scleromystax species, the new taxon is most similar to $S$. macropterus, differing from this species mainly by the absence of a black spot on the base of the median caudalfin rays ( $v s$. presence), a higher number of pectoral-fin rays (I,8,i vs. I,7,i), males with somewhat more slender bodies (25.7$30.5 \%$ in SL [range $26.3-28.8 \%$ in type series] vs. 30.4-34.6\% in $\mathrm{SL})$, and transverse blotches along body more irregular than those in $S$. macropterus. In addition to differences in coloration, external features, and osteological characters noted above, the new species differs from $S$. barbatus (a sympatric species) by having a deeper caudal peduncle (12.3-15.3\% in SL [range 12.6-15.3\% in type series] vs. 8.0-12.0\% in SL), a 


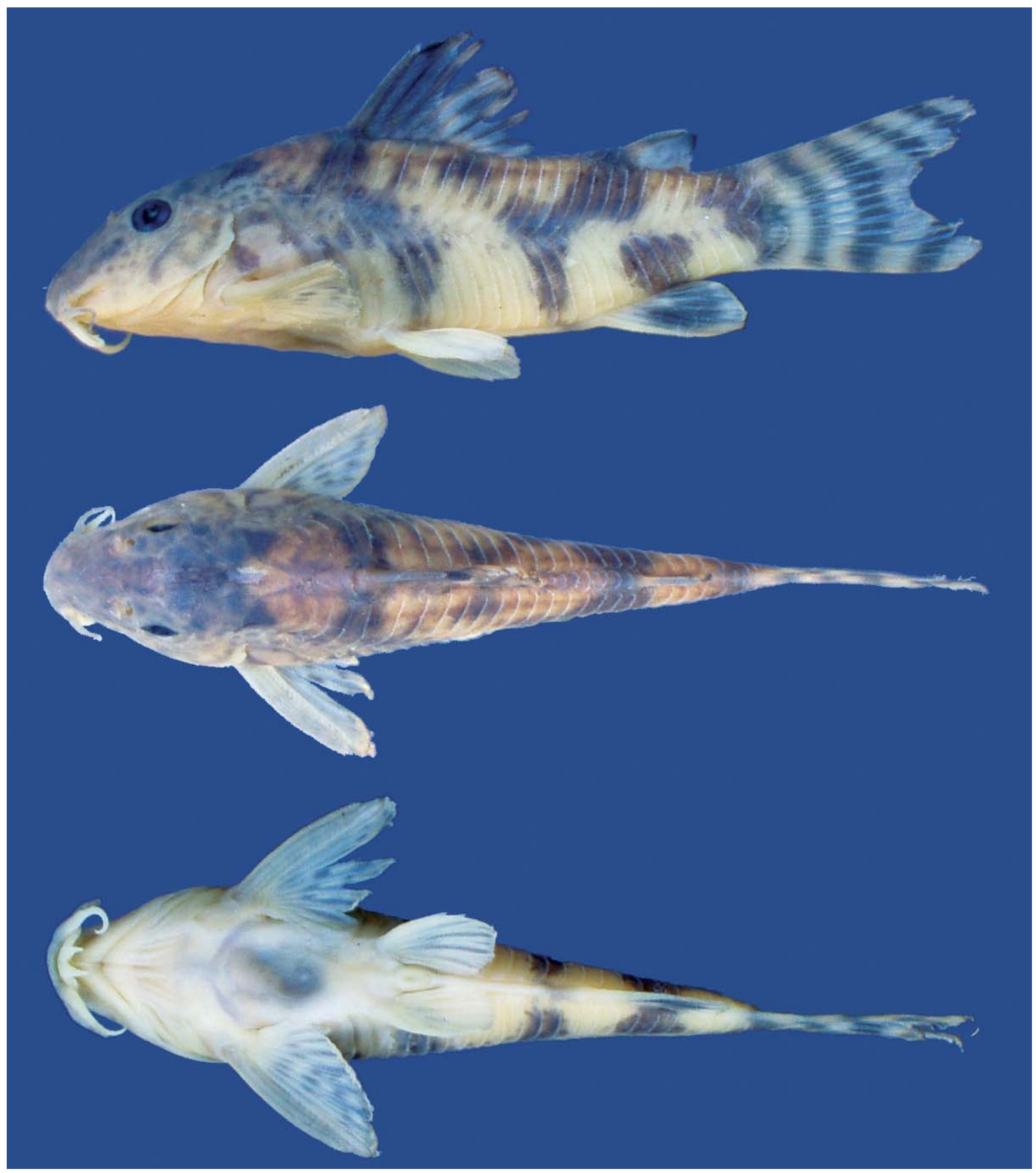

Fig. 1. Scleromystax salmacis, holotype, MCP 38388, female, 36.7 mm SL, arroio Molha Coco, Praia Grande, Santa Catarina, Brazil.

larger interorbital distance $(29.4-33.7 \%$ in HL [range 30.3$33.7 \%$ in type series] vs. $20.0-26.0 \%$ in HL), and a smaller snout length $(39.9-45.5 \%$ in HL [range $39.9-43.6 \%$ in type series] $v s$. $45.0-52.0 \%$ in HL).

Description. Morphometric data presented in Table 1. Head compressed with slightly convex dorsal profile in cross section and roughly triangular in dorsal view (Fig. 1). Snout rounded and slightly elongate. Head profile convex from upper lip to tip of posterior process of parieto-supraoccipital, with very slight convexity just anterior to nares. Profile of body slightly convex along dorsal-fin base. Postdorsal-fin body profile concave to adipose-fin spine; markedly concave from this point to caudal-fin base. Ventral profile of body nearly straight from isthmus to anal-fin origin, with pronounced convexity just anterior to pelvic fin. Profile markedly concave from first anal-fin ray to caudal-fin base. Body roughly elliptical in cross section at pectoral girdle, gradually becoming more compressed toward caudal fin.

Eye round, located dorsolaterally on head; orbit delimited dorsally by frontal and sphenotic, ventrally by infraorbitals. Anterior and posterior nares close to each other, only separated by flap of skin. Anterior naris tubular. Posterior naris close to anterodorsal margin of orbit, separated from orbit by 


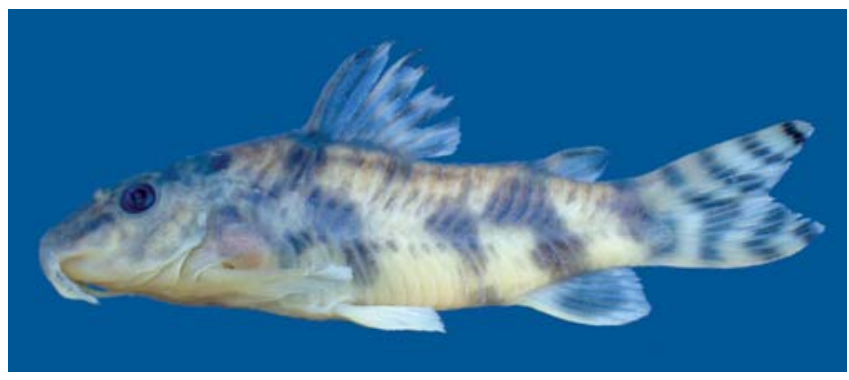

Fig. 2. Scleromystax salmacis, paratype, MCP 29299, male, 37.2 $\mathrm{mm}$ SL, arroio Molha Coco, Praia Grande, Santa Catarina, Brazil.

distance equal to twice diameter of naris. Mouth small, subterminal, width nearly equal to bony orbit diameter. Maxillary barbel elongate, reaching anteroventral limit of gill opening in some individuals. Maxillary barbel slightly longer than outer mental barbel. Inner mental barbel fleshy. Small rounded papillae cover entire surface of all barbels, upper and lower lips, and isthmus. Minute odontodes scattered between pectoral and pelvic girdles. Gill membranes united to isthmus. Four branchiostegal rays covered by thick layer of skin; distal two rays united at their tips by branchiostegal cartilage. Teeth on upper pharyngeal tooth plate 42(1) [38(1) or 39(2) in non-type specimens], and on fifth ceratobranchial 31(1) [29(1) or 30(2) in non-type specimens].

Nasal, frontal, sphenotic, compound pterotic, and parietosupraoccipital visible externally, all covered by thin layer of skin and bearing minute scattered odontodes. Frontal fontanel elongate, covered by thin layer of skin, and reaching middle of parieto-supraoccipital. Nasal slender, slightly curved laterally, mesial border contacting frontal and mesethmoid. Frontal roughly rectangular; anterior expansion in contact with nasal bone and mesethmoid, posterior portion contacting sphenotic and parieto-supraoccipital. Sphenotic trapezoid in shape, contacting parieto-supraoccipital dorsally, compound pterotic posteriorly, second infraorbital ventrally. Compound pterotic roughly pipe-shaped, with slender posterior expansion contacting first dorsal body plate dorsally, and first lateral-line ossicle posteriorly. Ventral margin of compound pterotic contacting opercle and cleithrum. Parieto-supraoccipital quadrangular with posterior expansion triangular and elongate, but not reaching nuchal plate. Minute odontode-bearing platelets between parieto-supraoccipital posterior process and nuchal plate.

Two narrow infraorbital bones, externally visible, covered by thin layer of skin; both bearing few minute odontodes. First infraorbital expanded anteriorly. Opercle exposed, ovoid in shape and roughly elongate, with angular free border. Preopercle externally visible, slender and covered by thin layer of skin. Interopercle triangular, partially covered by thin layer of skin, partially covered by thick skin. Opercle, preopercle, and interopercle with minute odontodes scattered over their surfaces.

Trunk lateral line composed of one perforated dorsolateral body plate and two laterosensory canals, reduced to small ossicles; one specimen (MCP 29299, $37.2 \mathrm{~mm} \mathrm{SL}$ ) without perforated dorsolateral body plates. Lateral-line canal entering neurocranium through compound pterotic, splitting into two branches before entering sphenotic: pterotic and preoperculomandibular each with single pore. Sensory canal continuing through compound pterotic, entering sphenotic as temporal canal, which splits into two branches: one branch giving rise to infraorbital canal, other branch entering frontal through supraorbital canal. Supraorbital canal with two branches: epiphyseal branch that opens in frontal bone, and anterior branch that runs through nasal bone. Nasal canal with single opening at each end. Infraorbital canal runs through entire second infraorbital, extending to infraorbital 1 and opening into two pores. Preoperculomandibular branch not connected to preoperculomandibular canal, which runs through entire preopercle with three openings, leading to pores 3, 4, and 5 , respectively.

Body plates with minute odontodes restricted to posterior margins. Nuchal plate exposed. Cleithrum exposed laterally. Dorsolateral body plates not touching counterparts at middorsal line. Narrow middorsal groove extends from last dorsal-fin ray to first preadipose platelet. Dorsolateral body plates 25(1) or 26*(4) [25(1), 26(8), 27(4), or 28(1) in non-type specimens]; ventrolateral body plates $23 *(5)$ [23(4), 24(8), or 25(2) in non-type specimens]; dorsolateral body plates along dorsal-fin base 6(2) or $7 *(3)$ [6(5), 7(8), or 8(1) in non-type specimens]; dorsolateral body plates from adipose fin to caudal-fin base 7(2) or $8^{*}(3)$ [7(1), 8(7), or 9(6) in non-type specimens]; preadipose platelets 5(4) or 6*(1) [5(1), 6(3), 7(5), 8(3), 9(1), or 10(1) in non-type specimens]. Precaudal vertebrae 9(1) [8(2) or 10(1) in non-type specimens]; caudal vertebrae 15(1) [15(2) or 17(1) in non-type specimens]; 6(1) pairs of ribs, first pair conspicuously larger than others.

Dorsal fin roughly triangular; its origin just posterior to third dorsolateral body plate. Dorsal spine shorter than first three branched rays. Distal tip of dorsal spine slightly curved posteriorly. Anterior and posterior borders of dorsal spine smooth. Dorsal-fin rays I,7(1), I, $8 *(3)$, or I,9(1) [I,8(13) or I,9(1) in non-type specimens]. Adipose fin roughly triangular; its origin separated from base of last dorsal-fin ray by $8(2), 9^{*}(2)$, or 10(1) dorsolateral body plates. Anal fin roughly triangular; its origin located just posterior to 13 th ventrolateral body plate, at vertical through posterior margin of last preadipose platelet. Anal-fin rays ii,6*(3) or ii,7(2) [ii,5,i(6) or ii,6(8) in non-type specimens]. Pectoral fin roughly triangular; its origin located just posterior to gill opening. Ossified portion of pectoral spine shorter than first two branched rays. Distal tip of spine with minute segmented unossified portion. Pectoral spine with welldeveloped serrations along entire posterior border. Pectoral-fin rays $\mathrm{I}, 8, \mathrm{i}^{*}(5)[\mathrm{I}, 8, \mathrm{i}(12)$ or $\mathrm{I}, 9, \mathrm{i}(1)$ in non-type specimens, one specimen (UFRJ 140, $33.7 \mathrm{~mm} \mathrm{SL}$ ) I,6,i]. Ventral keel of scapulocoracoid orientated to anterior margin of bone, its anterior portion surpassing horizontal through middle of mesial border of scapulocoracoid (Fig. 3). Pelvic fin ellipsoidal; its origin just below second ventrolateral body plate, at vertical through base of third branched dorsal-fin ray. Pelvic-fin rays i,5*(5). Caudal fin bilobed; both lobes equal in size. Principal 


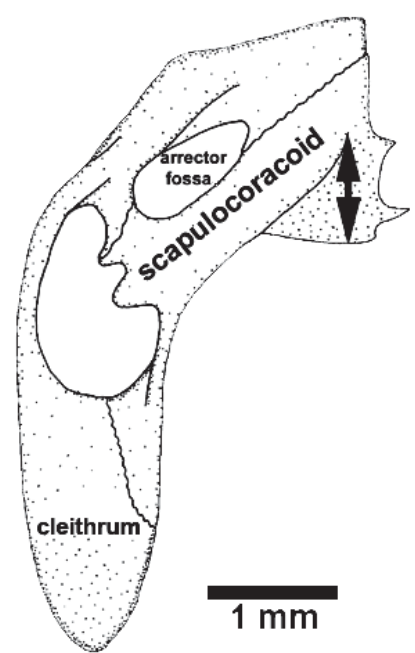

Fig. 3. Ventral view of right pectoral girdle of Scleromystax salmacis, paratype, MCP 29299, $33.2 \mathrm{~mm}$ SL. Double-headed arrow showing orientation of the proximal portion of the ventral keel of the scapulocoracoid.

caudal-fin rays i,6/6,i, one specimen (MCP 29299, $34.9 \mathrm{~mm} \mathrm{SL}$ ) i,6/4,i; five upper and four lower procurrent caudal-fin rays. All fins with minute odontodes scattered over all rays.

Color in alcohol. Ground coloration of head light brown. Small, irregular, dark brown blotches scattered over dorsal and lateral surface of head and snout. Several concentrated chromatophores forming irregular dark brown stripe along side of snout from anteroventral margin of orbit to corner of mouth. Anterior naris with series of minute brown chromatophores more concentrated at margin. Thin faint brown ring surrounding orbit. Maxillary and outer mental barbels light brown, with minute, scattered, small dark brown blotches on proximal half. Inner mental barbel unpigmented. Preopercle brown. Chromatophores scattered over preopercle, opercle and region corresponding to adductor mandibulae muscle, forming several irregular small blotches, more concentrated on free border of opercle and region of articulation between opercle and interopercle. Ventral region of head yellowish white, with few scattered chromatophores on branchiostegal membranes close to cleithrum.

Ground color of trunk light brown. Large dark brown blotch on cleithrum, faint in its middle region. First dorsolateral body plate with dark brown blotch encompassing its anteroventral region and posteroventral region of parieto-supraoccipital. Three large, irregular, roughly elongate, dark brown blotches along body plates; largest blotch, just below dorsal spine, with dorsal extension reaching dorsal-spine base, and ventral extension reaching to pelvic-fin base; second blotch between dorsal and adipose fins, with ventral expansion reaching ventral tip of ventrolateral body plate; and third blotch just below adipose-fin spine (confluent with second blotch in some specimens), extending from preadipose platelets to anal-fin base. Several chromatophores forming small, irregular, faint blotches between first and second trunk blotches.
Irregular, faint-brown, thin stripe on dorsal portion of dorsolateral body plate between first dorsal-fin ray base and third trunk blotch. Small, irregular, dark brown blotch just below last dorsal-fin ray. Several scattered chromatophores on dorsolateral body plate. Irregular, roughly curved, dark brown blotch on caudal peduncle; confluent with caudal fin pigmentation in some individuals. Ventral surfaces of body yellowish white.

Ground color of all dorsal-fin elements yellowish white; interradial membranes hyaline. Roughly triangular, diffuse blotch from dorsal spine to fourth/fifth branched dorsal-fin ray. Several chromatophores forming diffuse irregular stripe on mid-distal portion from second or third to sixth dorsal-fin branched rays; some individuals with several chromatophores on distal tip of fin from third to sixth branched ray. Scattered chromatophores on last two dorsal-fin rays. Ground color of anal-fin rays yellowish white. Interradial anal-fin membranes hyaline. Diffuse brown stripe on middle region of anal fin, not including anal-fin unbranched ray. Adipose-fin spine light brown with dark brown blotch on distal tip. Adipose-fin membrane with several scattered chromatophores, more concentrated on posterior border. Three to four series of small, diffuse, dark brown blotches restricted to pectoral-fin rays, not extending onto membranes. Ground color of all pectoral-fin rays and spine light brown; interradial membranes hyaline. Pectoral spine with scattered dark brown chromatophores. Pelvic fin hyaline, with diffuse brown blotch on mid-proximal portion from second to fourth unbranched ray. Ground color of caudal-fin rays yellowish white; caudal-fin membranes hyaline. Caudal fin with three to four series of small, dark brown blotches restricted to rays and forming poorly defined arched thick bands.

Sexual dimorphism. According to Nijssen \& Isbrücker (1980:135) and Britto (2003), corydoradine males can be recognized by the lanceolate shape of the genital papilla. However, this condition is unreliable as a means for distinguishing the sexes in smaller individuals (juveniles) (Nijssen \& Isbrücker, 1980; Lima \& Britto, 2001). Among previously described Scleromystax species males with well-distinguishable genital papillae also have other dimorphic features that help to distinguish them (see Diagnosis), although those features show a variable degree of development within the genus (see Discussion). Scleromystax salmacis sampled in the present study has no dimorphic conditions besides the shape of the genital papillae at any stage of development (compare Figs. 1 and 2), raising some questions as to the most useful features to distinguish Scleromystax (see Discussion).

Habitat and ecological notes. The type locality is a small pond near the arroio Molha Coco. The pond is surrounded by grass and is partially shaded by low trees and bamboo shrubs. The water is clear and slow flowing, and the bottom is formed by rocks covered by a thin layer of mud. The pond is fed by a very small creek and is periodically flooded by the main stream. Other species collected along with Scleromystax salmacis at 
Table 1. Morphometric data of Scleromystax salmacis.

\begin{tabular}{|c|c|c|c|c|c|c|c|c|c|}
\hline & \multirow[t]{3}{*}{ Holotype } & \multicolumn{4}{|c|}{ Paratypes } & \multicolumn{4}{|c|}{ Non-type specimens } \\
\hline & & \multicolumn{2}{|c|}{ Females } & \multicolumn{2}{|c|}{ Males } & \multicolumn{2}{|c|}{ Females } & \multicolumn{2}{|c|}{ Males } \\
\hline & & $\operatorname{Mean}(n=5)$ & Range & $\operatorname{Mean}(n=3)$ & Range & $\operatorname{Mean}(n=4)$ & Range & $\operatorname{Mean}(n=5)$ & Range \\
\hline $\begin{array}{l}\text { Standard length }(\mathrm{mm}) \\
\text {. }\end{array}$ & 36.7 & 37.8 & $30.7-48.2$ & 34.4 & $32.9-37.2$ & 45.6 & $37.9-53.1$ & 32.5 & $31.0-33.8$ \\
\hline \multicolumn{10}{|l|}{ Percents of Standard length } \\
\hline Depth of body & 29.8 & 28.5 & $25.8-30.9$ & 27.8 & $26.3-28.8$ & 28.5 & $27.1-29.1$ & 28.2 & $25.7-30.5$ \\
\hline Predorsal distance & 45.9 & 46.7 & $44.1-48.8$ & 48.1 & $47.1-49.9$ & 44.4 & $43.4-45.8$ & 45.7 & $44.7-47.9$ \\
\hline Prepelvic distance & 47.2 & 48.1 & $46.2-50.8$ & 49.1 & $47.8-49.8$ & 45.7 & $44.2-46.5$ & 47.3 & $46.4-48.3$ \\
\hline Preanal distance & 77.3 & 78.5 & $77.2-79.7$ & 79.1 & $78.6-79.5$ & 77.3 & $76.6-78.9$ & 76.3 & $73.6-77.6$ \\
\hline Preadipose distance & 84.1 & 84.1 & $83.2-85.4$ & 84.1 & $83.0-85.6$ & 83.1 & $82.2-84.4$ & 83.6 & $81.1-85.5$ \\
\hline Length of dorsal spine & 15.4 & 14.9 & $10.4-17.5$ & 16.6 & $16.1-17.0$ & 13.7 & $12.7-15.4$ & 14.1 & $12.5-15.4$ \\
\hline Length of pectoral spine & 22.0 & 20.9 & $19.1-24.5$ & 22.8 & $21.6-23.9$ & 19.8 & $18.1-21.6$ & 20.6 & $18.0-22.4$ \\
\hline Length of adipose-fin spine & 9.1 & 9.1 & $7.9-11.1$ & 9.9 & $9.2-10.6$ & 8.6 & $7.8-9.9$ & 9.7 & $8.9-10.2$ \\
\hline Depth of caudal peduncle & 13.8 & 13.4 & $12.6-14.0$ & 14.4 & $13.7-15.3$ & 12.7 & $12.3-13.6$ & 13.9 & $13.1-14.5$ \\
\hline Dorsal to adipose distance & 22.8 & 24.3 & $21.9-27.2$ & 23.5 & $22.6-24.4$ & 25.4 & $23.1-26.4$ & 23.4 & $21.8-24.6$ \\
\hline Length of dorsal-fin & 18.5 & 18.2 & $16.7-21.2$ & 18.6 & $17.8-19.2$ & 17.1 & $16.5-17.8$ & 17.3 & $16.1-18.8$ \\
\hline Maximum cleithral width & 13.0 & 12.5 & $11.9-13.6$ & 12.1 & $11.6-12.4$ & 14.3 & $11.7-15.9$ & 13.5 & $12.1-14.8$ \\
\hline Head length & 39.1 & 38.0 & $36.0-39.9$ & 38.7 & $37.8-39.6$ & 36.1 & $34.9-37.1$ & 36.5 & $35.1-37.4$ \\
\hline Length of maxillary barbel & 11.9 & 11.5 & $5.3-14.6$ & 13.8 & $9.9-16.1$ & 13.4 & $9.6-18.5$ & 12.3 & $8.8-16.6$ \\
\hline \multicolumn{10}{|l|}{ Percents of Head length } \\
\hline Head depth & 76.7 & 74.1 & $73.2-74.8$ & 73.3 & $72.3-74.1$ & 73.5 & $72.1-76.1$ & 73.8 & $70.7-76.6$ \\
\hline Least interorbital distance & 30.3 & 31.9 & $30.3-33.7$ & 31.5 & $30.3-32.5$ & 30.0 & $29.4-30.4$ & 32.3 & $29.8-33.5$ \\
\hline Horizontal orbit diameter & 18.5 & 18.6 & $16.3-21.5$ & 18.0 & $17.9-18.2$ & 17.0 & $15.6-18.4$ & 20.4 & $19.1-21.6$ \\
\hline Snout length & 39.9 & 41.8 & $40.6-42.9$ & 42.1 & $40.5-43.6$ & 43.6 & $42.7-44.5$ & 42.8 & $40.7-45.5$ \\
\hline Least internareal distance & 17.9 & 18.5 & $17.0-22.0$ & 19.8 & $17.6-23.0$ & 20.1 & $19.2-21.6$ & 20.0 & $18.8-21.1$ \\
\hline
\end{tabular}

the type-locality are Steindachnerina biornata, Mimagoniates rheocharis, Astyanax scabripinnis, Hollandichthys sp., Rineloricaria aequalicuspis, Pareiorhaphis nudula, and Phalloceros caudimaculatus. The rio Ratones, on the other hand, has a sandy bottom and specimens were collected on an open, sand bank.

Distribution. Rio Mampituba and rio Araranguá basins in southern Santa Catarina State of Brazil (Fig. 4). Non-type specimens were collected in the rio Ratones, a small coastal river drainage in Florianópolis. This species has the southernmost distribution in the genus.

Etymology. Scleromystax salmacis, is named after the character of Ovid's tale, "The fountain of Salmacis". From the Greek Salmacis, a nymph who had fallen in love with Hermaphroditus, the son of Hermes and Aphrodite. To avoid letting him go, Salmacis leapt upon him, and they both tumbled into the waters of her fountain, legs and arms twisted around each other. Filled with despair, the nymph shouted to the heavens, imploring the Fates or the gods never to allow the two of them to be separated. From her strength of will and his divine heritage, between the thrashing of the pure water and the twisting of limbs, the two merged into one form. It had one pair of arms, one set of legs, one head and one face but was both male and female at the same time. So Hermaphroditus, who was both male and female in name, cursed the pool for making him the same in body. To this day men hesitate to drink or bathe in waters taken from the fountain of Salmacis in fear that a similar fate shall befall them as well.

In allusion to its very subtle sexual dimorphism when compared to other Scleromystax species. A noun in apposition.

\section{Discussion}

Scleromystax salmacis is known from the arroio Molha Coco near Praia Grande, its type locality, and the rio Cedro Alto in Nova Veneza, both localities in Southern Santa Catarina. The type locality belongs to the rio Mampituba basin and the rio Cedro Alto is a tributary to the rio Araranguá. Both rivers are part of a well known area of fish endemism already discussed by Reis \& Schaefer (1998), Reis \& Cardoso (2001), and Malabarba \& Weitzman (2003), which includes the Maquiné, Três Forquilhas, Mampituba, and Araranguá rivers. The third locality where specimens were captured is the rio Ratones, a small coastal river in the Santa Catarina Island. Because of geographic disjunction and small morphological differences, specimens from this last locality were not considered as part of the type series.

Scleromystax salmacis is unique among its congeners mainly by not displaying the remarkable suite of sexually dimorphic characters, viz. males with developed odontodes inserted in fleshy papillae on the preopercular-opercular region, and with dorsal and pectoral fins 2-3 times as long as those of females. Although these dimorphic features represent the most easily recognizable subset of derived character states that diagnose Scleromystax (Britto, 2003), there are somewhat distinct levels of development of those conditions within the genus.

These dimorphic features are remarkably pronounced in S. barbatus, with dorsal and pectoral fins of males reaching, or almost reaching, the caudal peduncle, and well-developed odontodes inserted in fleshy tissue on a large area on the sides of the snout in fully grown males (maximum SL nearly $80.0 \mathrm{~mm}$ in a specimen examined during the present study; MNRJ 19622). Although males of S. macropterus can have 


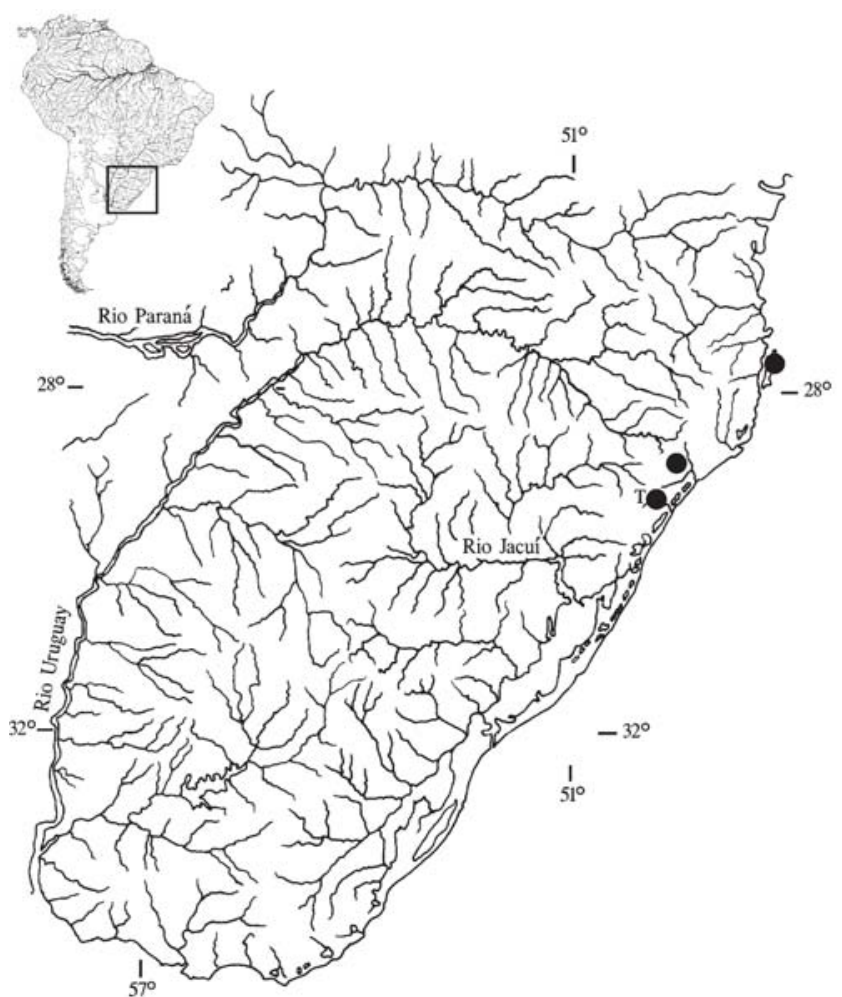

Fig. 4. Geographic distribution of Scleromystax salmacis. $\mathrm{T}=$ type-locality.

dorsal and pectoral fins proportionally longer than those of S. barbatus (maximum SL nearly 50.0; UFRJ 202), odontodes on the sides of the snout are much smaller, scattered, and cover a smaller area. Interestingly, the most conspicuous differences between both species concern young males, recognized as such by the lanceolate genital papillae.

Young males of S. barbatus (nearly $37 \mathrm{~mm} \mathrm{SL}$ ) already show well-developed odontodes on the sides of the snout, although their dorsal and pectoral fins are not distinguishable from those of females, indicating that the development of cheek odontodes precedes fin elongation during ontogeny. In S. macropterus, males up to $31.0 \mathrm{~mm}$ SL are recognized only by their genital papillae, with slightly larger individuals displaying fleshy tissue on the sides of the snout, but without odontodes. In contrast to $S$. barbatus, males of $S$. macropterus with incipiently developed odontodes (nearly $33.0 \mathrm{~mm}$ SL) also have dorsal and pectoral fins longer than females, although not fully developed. In summary, these features suggest distinct times of acquisition of secondary sexual-dimorphic conditions during the ontogeny of both species.

Differing from $S$. barbatus and $S$. macropterus, but similar to $S$. salmacis, young males of $S$. prionotos do not bear remarkably strong sexually dimorphic character states. Except for the lanceolate genital papillae and slightly distinct body proportions, only larger males of $S$. prionotos display sexually dimorphic characters. Even in these larger specimens, cheek odontodes and dorsal and pectoral-fin elongation are less evident when compared to males of $S$. barbatus and $S$. macropterus, as noted in an early description of the species
(Weitzman, 1955:105, as Corydoras nattereri triseriatus).

Another sexually dimorphic feature found in some Scleromystax species is the presence of a ventral skin fold in the first, unbranched pelvic-fin ray of larger females of $S$. barbatus and $S$. macropterus. However, no examined specimen of $S$. salmacis or $S$. prionotos displays this condition. Among callichthyid catfishes, a skin fold in the first pelvicfin element was first reported by Reis (1998: 152) as a derived state for the group composed of Hoplosternum, Megalechis, and Dianema. Although the function of this fold remains uncertain, Reis (1998) suggests that it could be useful for carrying eggs during spawning.

Although $S$. salmacis exhibits none of the sexually dimorphic conditions previously considered diagnostic of Scleromystax, the new species has all of the other character states that diagnose the genus, including a slender palatine and an elongate lateral ethmoid (Britto, 2003). In addition, the following additional exclusive characters are found to be shared by Scleromystax species: the presence of minute odontode-bearing platelets between the posterior tip of parieto-supraoccipital and nuchal plate (Fig. 5); and the posterior process of the parieto-supraoccipital and the nuchal plate are both elongate, reaching to, but not touching, each other. Both features are present in S. salmacis. The latter condition appears to be intermediate between the state found in Aspidoras (posterior process and nuchal plate both short, and well separated by 2 or 3 dorsolateral body plates) and Corydoras, except C. difluviatilis Britto \& Castro (posterior process and nuchal plate both very elongate, sutured to each other). In C. difluviatilis the posterior process and the nuchal plate are both elongate, and not reaching each other, similar to the condition found in Scleromystax. Considering the basal most position of $C$. difluviatilis within the genus, the present character state is ambiguous in the most parsimonious cladogram of the Corydoradinae: acquired in the ancestor of the subfamily and transformed to the other states in the ancestors of Aspidoras and Corydoras except C. difluviatilis, respectively (three steps); or, acquired in both the ancestors of Scleromystax and Corydoras, and transformed in the ancestor of Corydoras except $C$. difluviatilis. Despite the ambiguity, the condition of the posterior process of parieto-supraoccipital almost reaching nuchal plate could be useful for recognizing members of Scleromystax.

The inclusion of $S$. salmacis in the data matrix of Britto (2003) grouped this species with $S$. macropterus in a distal position within the genus, based on characters such as the shape of the posterior portion of the mesethmoid, the free margin of the opercle, and the degree of participation of mesethmoid/lateral ethmoid in the nasal capsule. This hypothesis brings new insights about the interpretation of the transitions concerning sexually dimorphic features, since the set of conditions presented by $S$. salmacis could be reversals instead of primitive states shared with other corydoradine catfishes. However, a more encompassing analysis of Scleromystax is necessary to bring more confidence to this hypothesis. 


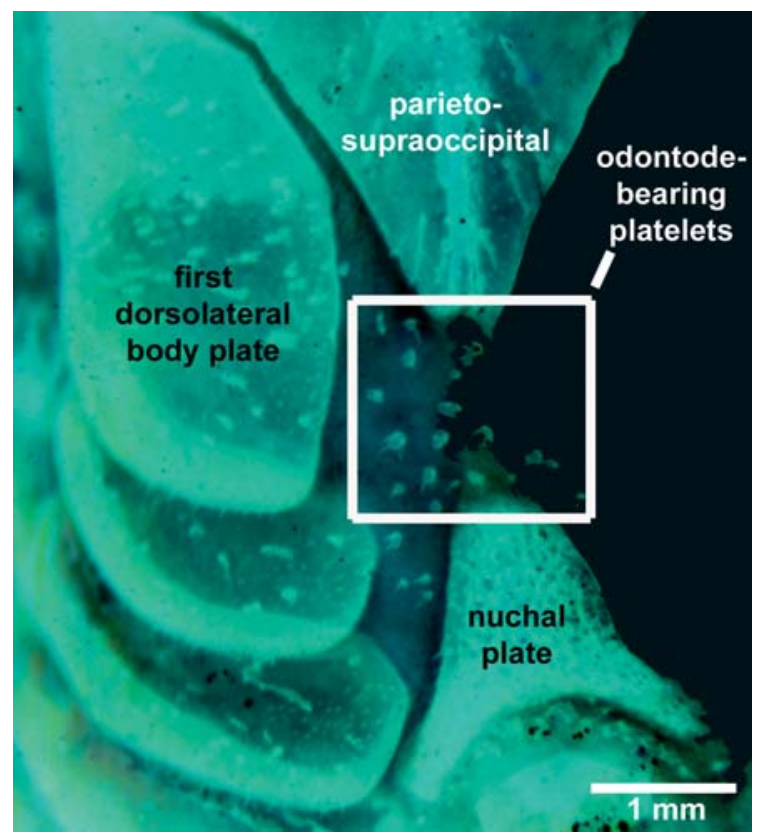

Fig. 5. Detail of top of head of Scleromystax salmacis, paratype, MCP 29299, $33.2 \mathrm{~mm} \mathrm{SL}$, showing minute odontodebearing platelets between posterior process of parieto-supraoccipital and nuchal plate.

\section{Acknowledgements}

We are indebted to M. Ghazzi (MNRJ) for help with photographs of type specimens and discussions during the present study, and to A. Netto-Ferreira (MNRJ) for suggestions on the manuscript and help with photographs of bones, suggesting the use of high-contrast negatives. We also like to thank H. Britski, J. Figueiredo, N. Menezes, O. Oyakawa, and M. de Pinna (MZUSP), and W. Costa (UFRJ) for the loan of specimens. Research associated with this paper was partially financed by the All Catfish Species Inventory (NSFDEB \#0315963). MRB received financial support from $\mathrm{CNPq}$ (Grant \# 300189/03-6); RER is partially financed by CNPq (Proc. \# 301748/2004-7).

\section{Literature cited}

Aquino, A. E. \& S. A. Schaefer. 2002. The temporal region of the cranium of loricarioid catfishes (Teleostei: Siluriformes): Morphological diversity and phylogenetic significance. Zoologischer Anzeiger, 241: 223-244.

Arratia, G. \& M. Gayet. 1995. Sensory canals and related bones of tertiary siluriform crania from Bolivia and North America and comparison with recent forms. Journal of Vertebrate Paleontology, 15: 482-505.

Britto, M. R. 2003. Phylogeny of the subfamily Corydoradinae Hoedeman, 1952 (Siluriformes: Callichthyidae), with a definition of its genera. Proceedings of the Academy of Natural Sciences of Philadelphia, 153: 119-154.

Britto, M. R. \& F. C. T. Lima. 2003. Corydoras tukano, a new species of corydoradinae catfish from the rio Tiquié, up- per rio Negro basin, Brazil (Ostariophysi: Siluriformes: Callichthyidae). Neotropical Ichthyology, 1(2): 83-91.

Lima, F. C. T. \& M. R. Britto. 2001. New catfish of the genus Aspidoras (Siluriformes: Callichthyidae) from the upper rio Paraguai system in Brazil. Copeia, 2001(4): 1010-1016.

Lundberg, J. G. 1970. The evolutionary history of North American catfishes, Family Ictaluridae. Unpublished Ph.D. Dissertation, The University of Michigan, Ann Arbor. xiii + 524p.

Malabarba, L. R. \& S. H. Weitzman. 2003. Description of a new genus with six new species from southern Brazil, Uruguay and Argentina, with a discussion of a putative characid clade (Teleostei: Characiformes: Characidae). Comunicações do Museu de Ciências e Tecnologia, PUCRS, Série Zoologia, 16(1):67-151.

Nijssen, H. \& I. J. H. Isbrücker. 1980. Aspidoras virgulatus n.sp., a plated catfish from Espírito Santo, Brazil (Pisces, Siluriformes, Callichthyidae). Bulletin Zoologisch Museum Universiteit van Amsterdam, 7: 133-138.

Reis, R. E. 1997. Revision of the Neotropical genus Hoplosternum (Ostariophysi: Siluriformes: Callichthyidae) with the description of two new genera and three new species. Ichthyological Exploration of Freshwaters, 7: 299-326.

Reis, R. E. 1998. Anatomy and phylogenetic analysis of the neotropical callichthyid catfishes (Ostariophysi, Siluriformes). Zoological Journal of the Linnean Society, 124: $105-168$.

Reis, R. E. 2003. Family Callichthyidae. Pp. 291-309 In. Reis, R. E., S. O. Kullander \& C. J. Ferraris (Eds.). Check list of the freshwater fishes of South and Central America. Edipucrs, Porto Alegre. 729p.

Reis, R. E. \& A. R. Cardoso. 2001. Two new species of Rineloricaria from southern Santa Catarina and northeastern Rio Grande do Sul, Brazil (Teleostei: Loricariidae). Ichthyological Exploration of Freshwaters, 12: 319-332.

Reis, R. E. \& S. A. Schaefer. 1998. New cascudinhos from southern Brazil: systematics, endemism, and relationships (Siluriformes, Loricariidae, Hypoptopomatinae). American Museum Novitates, 3254: 1-15.

Reis, R. E., S. O. Kullander \& C. J. Ferraris (Eds.). 2003. Check list of the freshwater fishes of South and Central America. Edipucrs, Porto Alegre. 729p.

Schaefer, S. A. 1988. Homology and evolution of the opercular series in the loricarioid catfishes (Pisces: Siluroidei). Journal of Zoology, 214: 81-93.

Schaefer, S. A. \& A. Aquino. 2000. Postotic laterosensory canal and pterotic branch homology in catfishes. Journal of Morphology, 246: 212-227.

Taylor, W. R. \& G. C. Van Dyke. 1985. Revised procedures for staining and clearing small fishes and other vertebrates for bone and cartilage study. Cybium, 9: 107-119.

Weitzman, S. H. 1955. Redescription and relationships of Corydoras triseriatus von Ihering from the Rio Doce, Brazil. The Wasmann Journal of Biology, 13(1): 101-106.

Received August 2005

Accepted October 2005 